The International Journal Of Engineering And Science (IJES)

|| Volume || 6 || Issue || 2 || Pages || PP 19-30 || 2017 ||

ISSN (e): $2319-1813$ ISSN (p): $2319-1805$

THE IJES

\title{
Paleoenvironment and Provenance Studies of Ajali Sandstone in Igbere Area, Afikpo Basin, Nigeria
}

\author{
S.O. Onyekuru, Okoro, Eze M., Opara, K.D., Agumanu, A.E. and Ikoro, D.O. \\ Dept. of Geology, Federal University of Technology, Owerri
}

\begin{abstract}
The stratigraphy and sedimentology of the Ajali Sandstone successions in Igbere area,Afikpo Basin were studied in order to determine plaeoenvironmental setting and sourcemodel of the deposits. The studied deposits consist of five lithofacies namely: pebblysandstone facies, cross-bedded, laminated, bioturbated sandstone facies and mudstonefacies. Paleoenvironmental interpretation based on facies associations and sedimentarystructures revealed tide-influenced fluvial deposits, while inferences from bivariate plotsof calculated univariate parameters indicated fluvial deposits. The granulometricanalyses of the sediments indicated a predominantly moderately sorted, medium-grainedsandstone with some poorly sorted populations. The kurtosis ranged from mesokurticthrough leptokurtic to extremely leptokurtic sand populations and generally with somesymmetrical, positive and negative skewness. This result is suggestive of a sandpopulation with different tails, especially for the facies representing the poorly sortedpopulations. The sandstone in the area is essentially quartz sandstone or quartz arenitebased on petrographic analysis. The relative abundance of the framework elements (Q96, F 0 and $R 4$ ) suggests super-mature sand with a maturity index $\geq 19.0$. Themineralogical and textural maturity of the sandstone therefore, indicated a polycyclicdeposit. This together with the constituent heavy minerals and paleocurrent directionsinferred that sources of detritus were from both the uplifted continental pluton and old sedimentary domain, respectively. The Crystalline Basement rocks of both theCameroon and Adamawa Highlands, the Oban Massif and western Nigeria Ilesha Spuron the one hand and the Abakaliki Anticlinorium on the other hand both satisfied suchsource models for the post-Santonian Ajali quartz-sand deposit.
\end{abstract}

Keywords: Paleoenvironment, Facies, Provenance, Maturity, Polycyclic, SourceModel.

Date of Submission: 14January2017Date of Acepted: 25 ebruary 2917

\section{INTRODUCTION}

The Nigerian sedimentary basins are broadly divisible into coastal Calabar Flank, NigerDelta, Dahomey (Benin) Basins and interior basins - Abakaliki, Makurdi, Wukari,Gongola Yola Arm, Chad, Nupe, SE Iullemmeden (Sokoto), Afikpo and AnambraBasins (Fig. 1).

The Afikpo Basin, located south-east of the Nigerian Southern Benue Trough, is aproduct of the second tectonic event responsible for the evolution of the southernNigerian sedimentary basins. This second episode- the Santonian-Maastrichtiancompressional folding, flexural inversion, faulting and alkaline-sub-alkaline magmatism-resulted in the formation of the Anambra and Afikpo Basins (Murat, 1972;Nwachukwu, 1972; Burke et al., 1972; Olade, 1975). Within the latter were depositedthe post-Santonian Nkporo Formation as the basal units on folded older strata. It issuperposed by an off lap complex of the coaliferous Mamu Formation, the AjaliSandstone and the paralic Nsukka Formation that terminated the Cretaceous proto-NigerDelta sedimentation in southern Nigeria.The first phase produced the Abakaliki-Benue Trough, the Calabar Flank and theMamfe Embayment, while the third phase gave rise to the Tertiary Niger Delta Basin(Umeji, 2010).

The geologic histories of both the Afikpo and Anambra Basins are thus related. Andlike the Anambra Basin the dispersal patterns, provenance and geographic extent of theAfikpo Basin have not been clearly ascertained (Onyekuru et al., 2013). Therefore, astudy synthesizing data accruing from lithofacies, sedimentary structures and petrologyand paleocurrent trend to infer the paleoenvironment, source model and paleogeographyof the lithostratigraphic units in the basin would aid in delineating spatial faciesrelationships and possible lithostratigraphic units' boundaries, thus enhancingcorrelation. Such an integrated multifaceted analysis would also provide a widespectrum of data source for a definitive environmental decision and source model forthe units. To achieve the aforementioned aim, the exposures in Igbere area have been chosen forthe study. The area lies within Latitudes $5^{\circ} 38^{\prime}$ and $5^{\circ} 43^{\prime} \mathrm{N}$ and longitudes $7^{\circ} 38^{\prime}$ and $7^{\circ} 45^{\prime} \mathrm{E}$ in the Afikpo Basin, Nigeria (Fig. 2). According to Ibe (2004), the exposure atIgbere is subdivided into a quartz -rich subjacent unit which is overlain by bioturbatedsub-facies. The latter unit grades upwards into bands with profuse trace fossils ofOphiomorpha isp, especially, in the section south of Abiriba. 


\section{REGIONAL STRATIGRAPHY AND BASIN FILL}

Murat (1972), Olade (1975) and Petters (1978) identified three main unconformityboundsedimentary packages which were deposited in Nigeria in response to theupwelling and cessation of mantle plume under the present Niger Delta. The packagesare Albian-Cenomanian, Turonian-Santonian and Campanian-Maastrichtian. The deposition of the packages was controlled by several factors including epeirogenicmovements resulting in transgressive and regressive movements of the sea cycles,worldwide eustatic changes in sea level, basin tectonism and local diastrophism (Murat,1972; Agumanu, 2009; Odigi, 2012). The Albian-Cenomanian transgressive pulse isrepresented in southern Nigeria by the Asu River Group - the oldest marine sedimentary deposit in the Southern Benue Trough. The group is composed of the AbakalikiFormation (Mid Albian) and the Late Albian-Cenomanian Ebonyi Formation(Agumanu, 1986; 1989).

The Turonian-Santonian transgressive phase deposited the Eziyiaku and AwguFormations (Petters and Ekweozor, 1982; Agumanu 1986; 2011). The former is a thickflaggy, grey or black calcareous shale and siltstone with limestone which grades intothick sandstone sequences such as the Amasiri Sandstone, the Makurdi Sandstone andthe Agala Sandstone(Murat, 1972; Dessauvagie, 1975; Hoque, 1977; Banerjee, 1980; Nwajide, 1982). Alater deposit, the super-adjacent Awgu Formation, is composed of lower limestone shaleand upper feldspathic and glauconitic sandstone (Agumanu, 2011).

The paralic Enugu Formation, Coal Measures (Mamu and Nsukka Formations) and theAjali Sandstone were deposited in the Anambra Basin (Tijani and Nton, 2010). TheNkporo Formation with intertongues of the Afikpo Sandstone - lateral equivalents of theEnugu Formation and the Owelli Sandstone (Campanian) - were deposited in the AfikpoBasin (Nwajide, 2005). The Nkporo Formation dated with SyncolporitesLisamaesubtilis and auriculi ditto sp. (Ojoh, 1990), and the Enugu Formation mark thebeginning of the third Cretaceous marine depositional cycle in southern Nigeria.

The Nkporo Formation comprises of dark grey, often friable, shale with occasional thinbands of limestone and intertonguing of the Afikpo Sandstone. Sedimentation continuedin the Afikpo Basin throughout the Campanian to the Oligocene as demonstrable onFig. 3 and Table 1 with a large offlap complex of the paralic Mamu Formation followedby the fluvio-deltaic sequence of the Ajali Sandstone (Tijani and Nton, 2009) andsuperposed by the paralic Nsukka Formation which together constitute the CoalMeasures Group of Umeji (2010), deposited on the Nkporo Formation.

The Ajali Sandstone (Maastrichtian), the False Bedded Sandstone of Simpson (1954), isan extensive sandstone body covering a vast area of southern Nigeria and beyond. Sincethe description and formalization by Reyment (1965) of the sedimentary formations insouthern Nigerian sedimentary basins, the study of the Ajali Sandstone has receivedconsiderable attention by several workers (Hoque, 1977; Hoque and Ezepue, 1977;Amajor, 1986; Ladipo, 1986; Anyanwu and Arua, 1990). On the bases of paleocurrentstudies, mineralogical analysis and provenance decision, the formation was consideredto have been derived from the Post-Santonian Abakaliki Anticlinorium (Nwachukwu,1972; Murat, 1972; Amajor, 1987). Different workers had adduced differentpaleoenvironmental settings for the sandstone on the basis of sedimentological analysisnamely, fluvial (Murat, 1972); fluvio-deltaic (Reyment, 1965; Hoque and Ezepue, 1977)and fluvio- marine (Amajor, 1987).

The present study synthesizes data from lithofacies, sedimentary structures andpetrology and paleocurrent trend to infer the paleoenvironment, source model andpaleogeography of sediments in Igbere area.

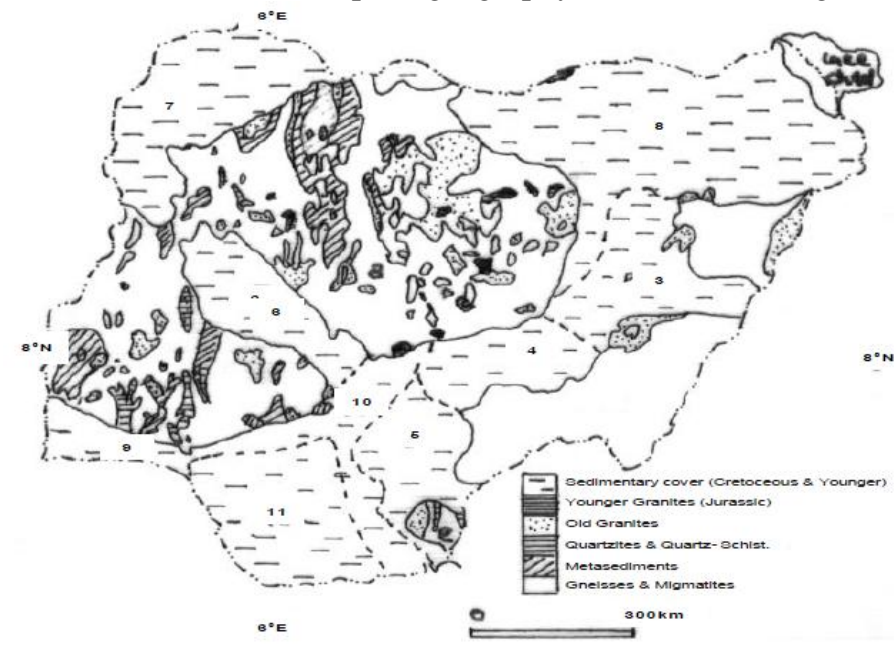

Fig. 1. Geological Sketch Map of Nigeria showing the bounds of sedimentary basins.Sedimentary Basins are numbered as described: 3. Northern Benue Trough, 4 CentralBenue Trough, 5 Southern Benue Trough (Afikpo

Syncline), 6 Bida Basin, 7Iullemmeden Basin, 8 Chad Basin, 9 Dahomey Basin, 10 Anambra Basin, 11 NigerDelta Basin (After Nwajide, 2005) 


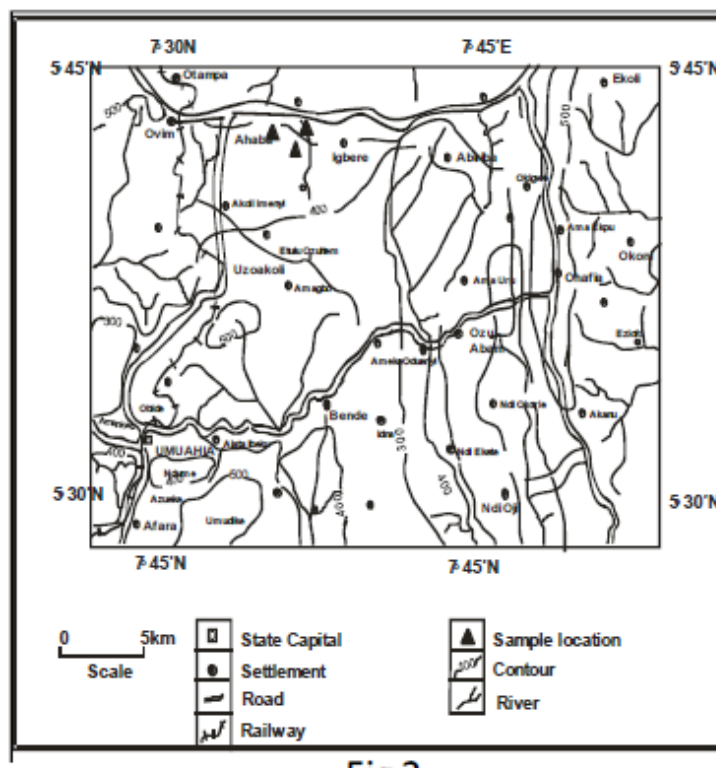

Fig 2

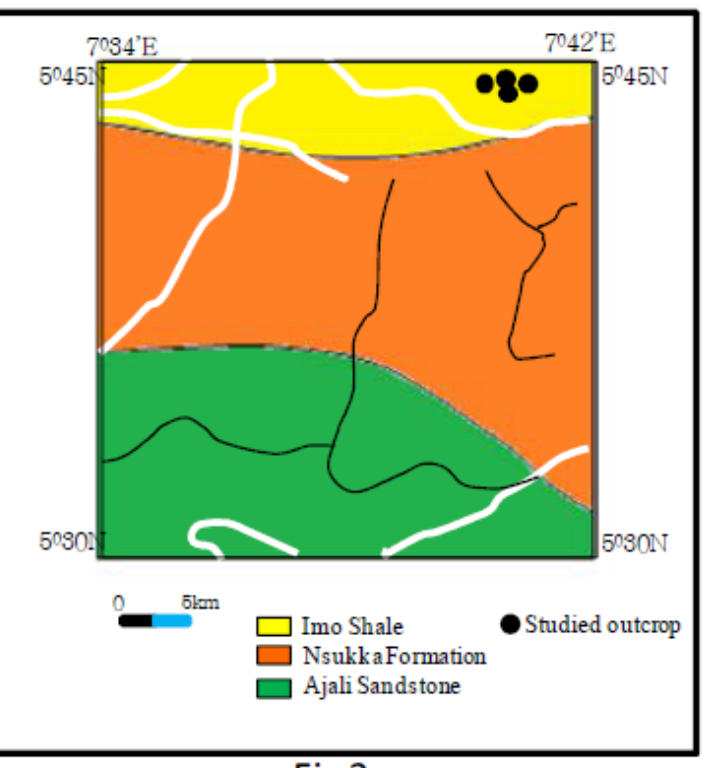

Fig 3

Fig. 2. Topographic Map Map of Igbere and

Fig. 3. Geologic Map of Igbere and

Environs, showing accessibility and sample locations sampleLocations

Table 1. Stratigraphic correlation of the southeastern Nigerian basins(Modified after Nwajide, 2005)

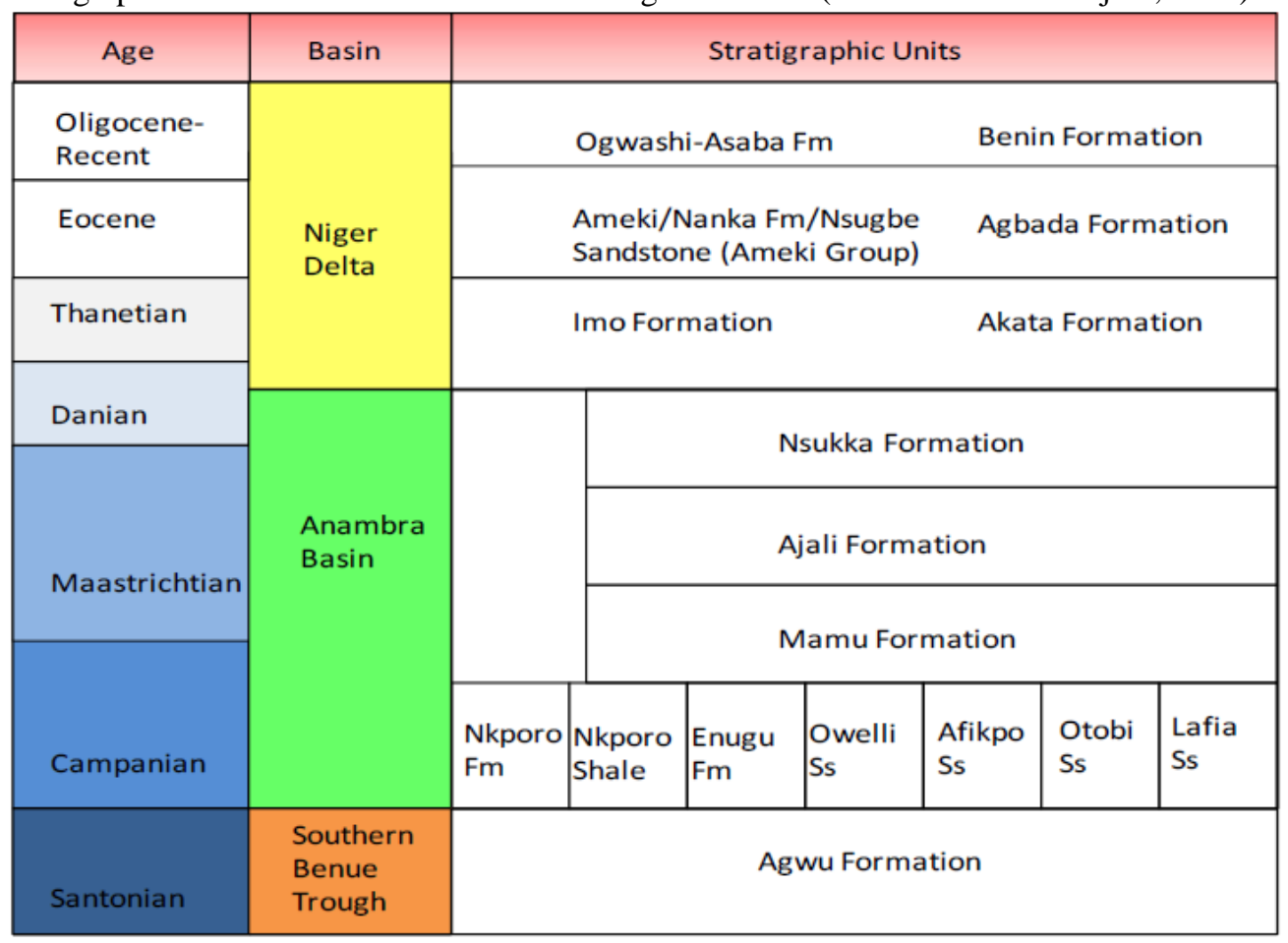

\section{Sedimentological Studies}

\section{METHODOLOGY}

Detailed descriptions, measurements and sampling of profiles of the Ajali Formationwere done at Igbere area and its environs. An E - Trex global positioning system (GPS)was used to determine and geo-reference the positions of the outcrops on the base map.Sedimentological study of the sections involved description and sampling of the variouslithological successions, appraisal of the physical and biogenic sedimentary structures and textural characterization of the exposed unit. The granulometric parameters andpetrologic studies were determined by conventional methods (Folk, 1974). Plots ofbivariate diagrams (Friedman, 1967; Moiola and Weisser, 1968) to discriminate thedepositional processes and characterize the environmental model were done. 
The dataaccruing from the studies were used to classify the Ajali Sandstone based on theschemes of Folk (1974); Iwuagwu and Lerbekmo (1982). Deductions frompaleoenvironmental and maturity studies of the deposits aided the determination ofprovenance derived from paleocurrent data of the Ajali Sandstone in Igbere area.

\section{Facies Analysis}

\section{RESULTS AND DISCUSSION}

Lithofacies analysis of the stratigraphic successions in the study area distinguished fivelithofacies namely, pebbly sandstone facies, cross-bedded sandstone facies, laminatedsandstone, bioturbated sandstone and mudstone facies. The distinguishing features ofeach facies are as follows:

Pebbly Sandstone Facies: The pebbly sandstone facies usually occurs towards thebase of sequences in the study area. They are usually poorly-bedded, fine-medium butoccasionally coarse grained sandstones with Ophiomorpha burrows and abundantmudclasts and conglomerates (Fig. 4).

Cross-Bedded Sandstone Facies: Cross-bedded sandstone facies are commonoccurrence in the exposures at Igbere and wherever the Ajali Sandstone outcrops. Thecross-beds include trough, planar, climbing rippled crossbeds and herring bone crossstratifiedunits according to Amajor (1986). The section commonly ranges from 0.7$5.0 \mathrm{~m}$ thick while the cross - strata are between 2 and $10 \mathrm{~cm}$ thick. Lithologically, they are

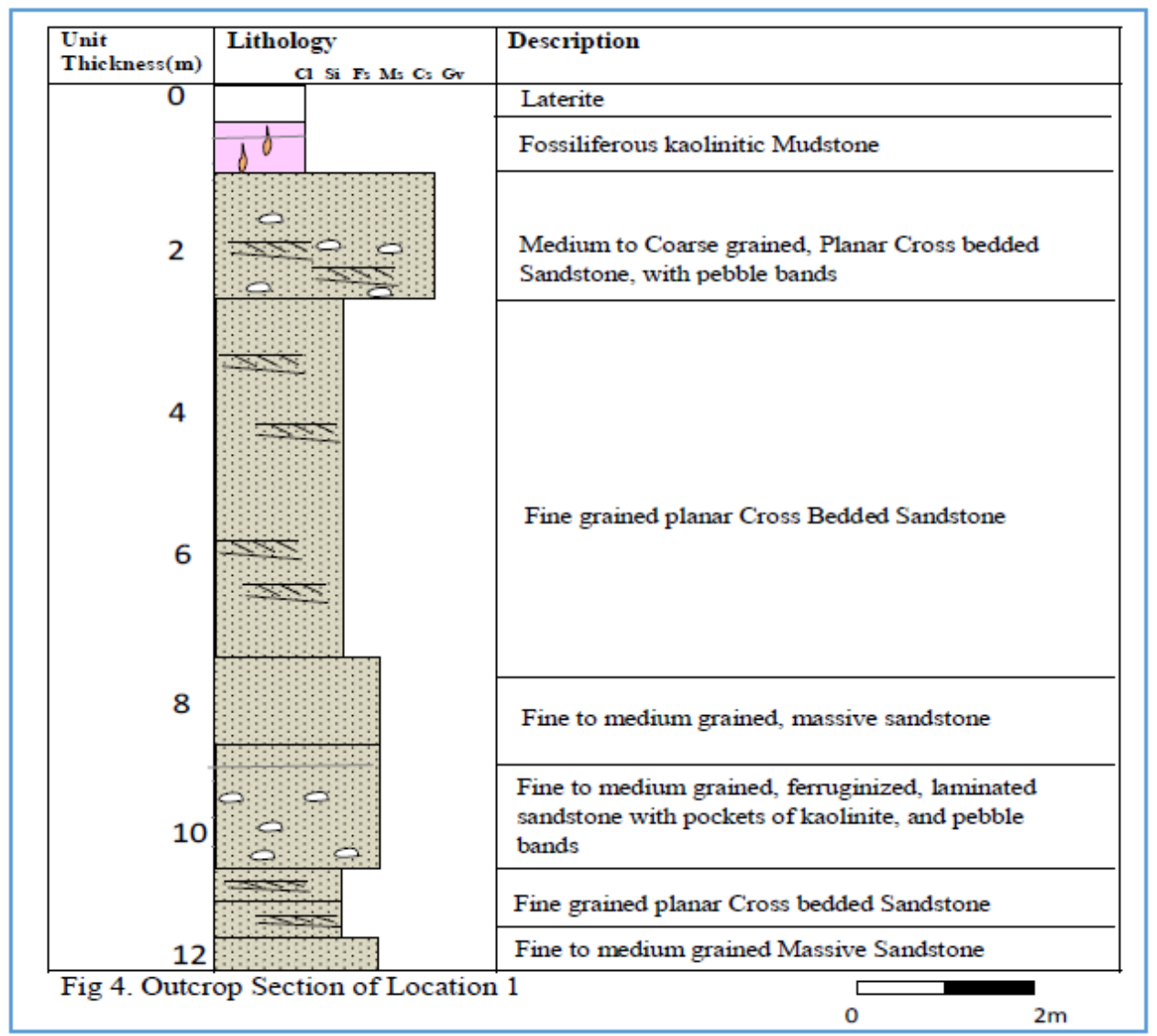

usually coarse-to medium-grained, fairly well sorted and sub-angular to sub-roundedwith fining-upward trends (FU).The fining-upwards strata terminate in laminations andcurrent and climbing ripples, (Fig. 5), with ripple indices of between 5 and 16 thusinferring water current ripples (Reineck and Singh, 1975). The top and bottom sets aremarked by laminated clay/siltstone drapes which are usually iron-stained (Fig. 5).

Some exposures are characterized by hydraulically deformed structures, convolute bedslaminations and stratifications. The deformations are said to be produced by the drag ofstrong sediment-laden current across the bottom and common in several environments.Some workers have used them to indicate turbidity current deposition because they areusually found in places where current and turbulence values are high (Coleman andGagliano, 1965). Overturning is oriented in a down current direction and the top of thefore-set lamination is usually truncated. 
The deformations were probably water escape structures and related to tectonic(earthquake) microseisms as opposed to storm induced shocks. They could also resultfrom rapid sedimentation and sporadic water in distal alluvial fan environment(Agumanu, 2009). Similar structures were described by Jones (1962) from theCretaceous Bima Sandstone in northeastern Nigeria and confirmed by Samaila et al.(2005) from the upper member of the Bima Sandstone in the Yola Arm, northeasternNigeria. The absence of apparent faulting or destruction in the convolution andorientation of the fold axes along the paleocurrent direction from our study probablysuggested that deformation occurred during or immediately after deposition (Samaila etal., 2005) or indicative of saturated condition.

This is because convolute beds are common place occurrences along river banks due tofalling river stage when super-saturated bank sediments tend to slump or readily subside(Coleman and Gagliano, 1965). They probably were triggered by liquefaction due toseismicity or rapid fluctuation of water table (Doe and Dott, 1980). They demonstratethe effect of hydrodynamic instability of the sediment due to rapid deposition in loosepackedstate arising from seismic shocks. The frequent occurrence of the structure ismore probably linked with pore-pressure buildup during earthquake other than stormeffect. (Johnson, 1977, Agumanu, 2009). There was probably syndepositionaltectonism and inherent loose sediment instability (Braide, 1992).

Laminated Sandstone Facies: This facies consists of laminated fine-grained lithologysiltstoneand claystone. They occur towards the top of the sequence and along theboundary with the overlying Nsukka Formation (Danian). Minor scour-and-fillstructures about $45 \mathrm{~cm}$ thick and approximately $100 \mathrm{~cm}$ long occur towards the top (Fig.6). Laminations are horizontal except where scours or channeling occurs. Contact ofchannel with the rest of the exposure is usually smoothed, brown-stained and sometimesclayey. They occur probably as a result of localized linear erosion or scouring andrepresent the downstream and distal terminal flood out channel sediments where theamount and size of coarse clasts are diminished.The fine grained silty sandstone contact and associated flat beds are reminiscent oflower flow regime (Wakelin-King and Webbs, 2007).

Bioturbated Mudstone Facies: This is an intensely burrowed siltstone and claystoneon the top of profiles with fine texture. The burrowing is usually horizontal and usuallyoverlies the coarse to medium- grained crossbedded unit. Isolated Ophiomorpha tracesmay occur in thicker laminated lithology (Figs. 4, 6 and 7). Ophiomorpha is considered

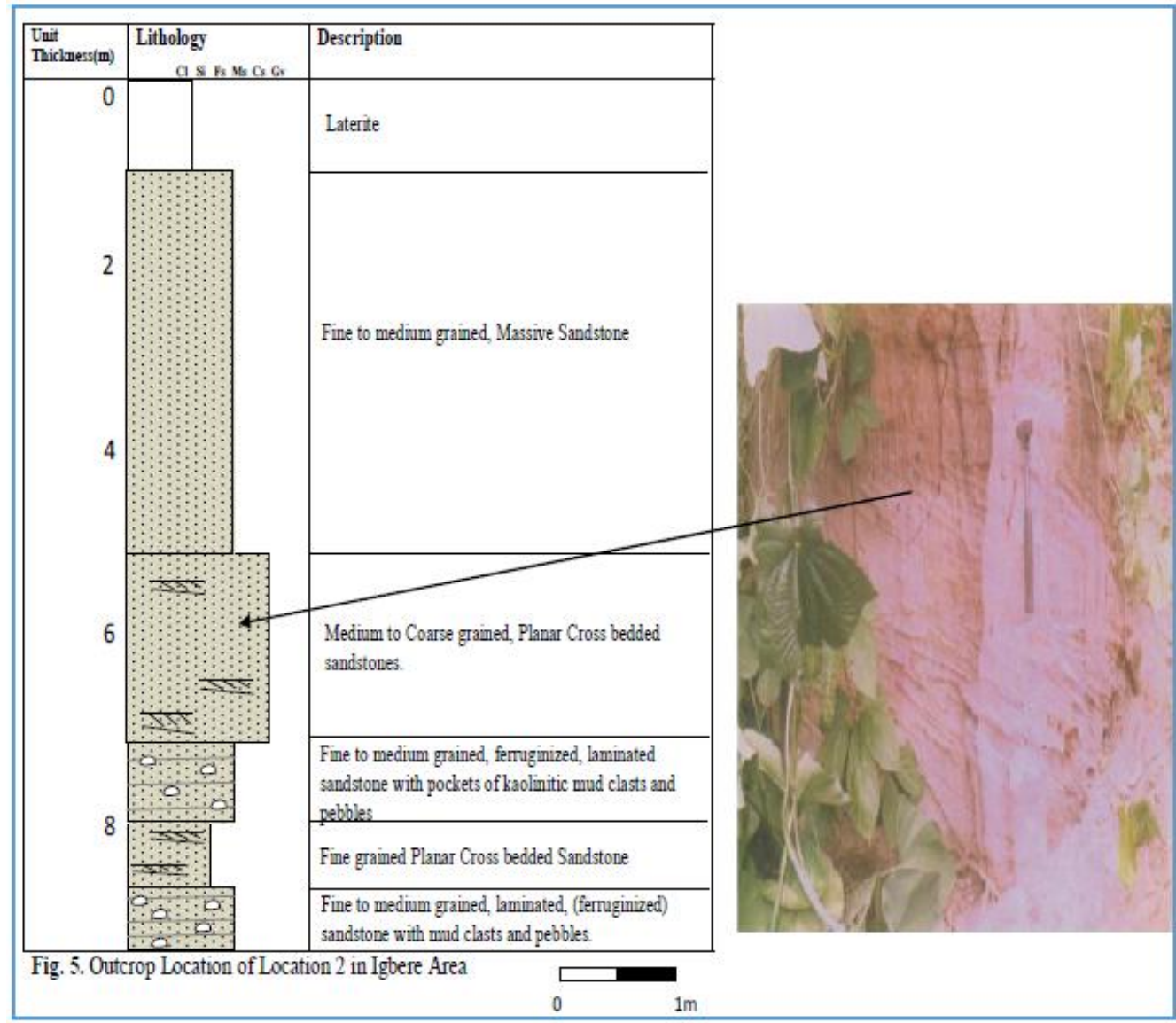




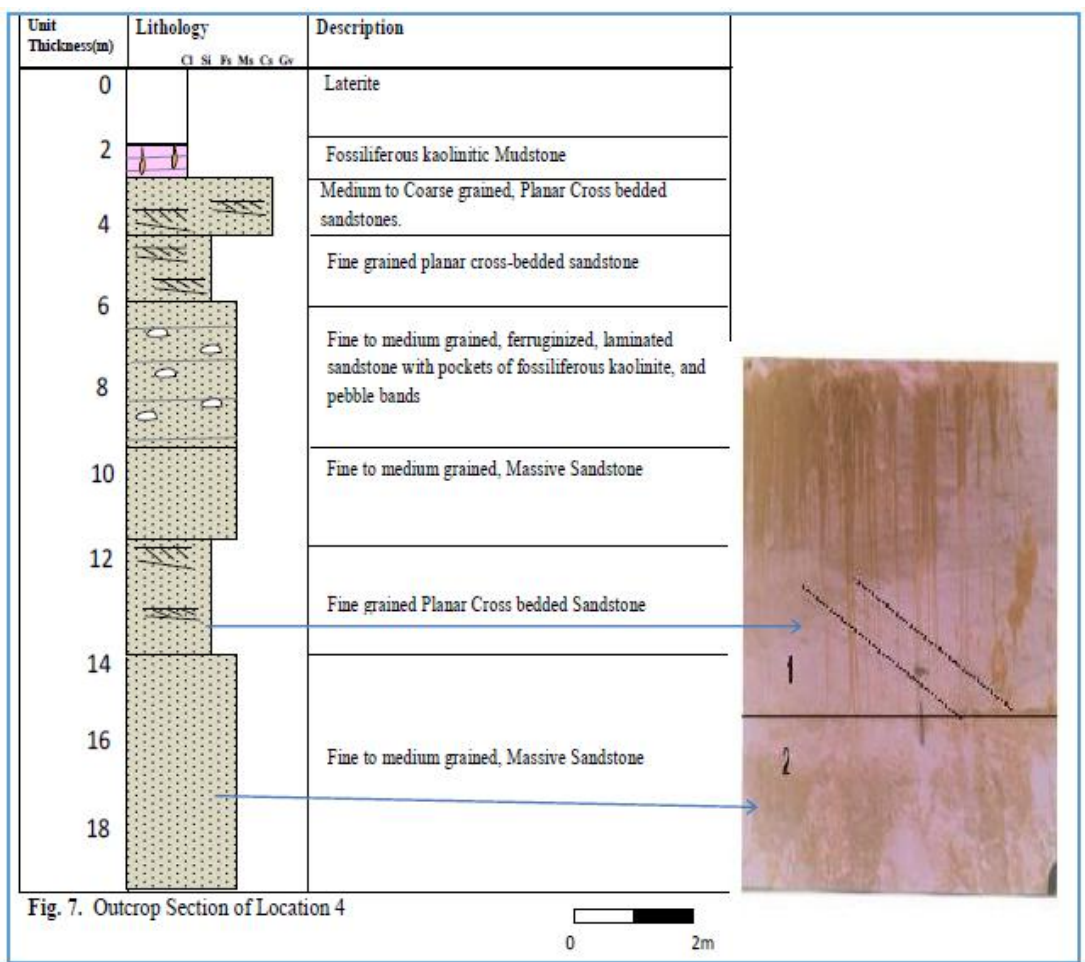

as part of the Skolithosichnofacies and as a burrowing organism living in the nearshoreenvironment (Onyekuru and Iwuagwu, 2010). The mudstone facies often terminates thesequence thus stimulating a generally finingupward (FU) sequence. The intensepreferential reworking and the preponderance of concentric diagenetic structures onsurfaces of this facies (Fig. 8) probably suggests epigenetic mineralization (Dill, 2012)especially as the section grades into the paralic Nsukka Formation.

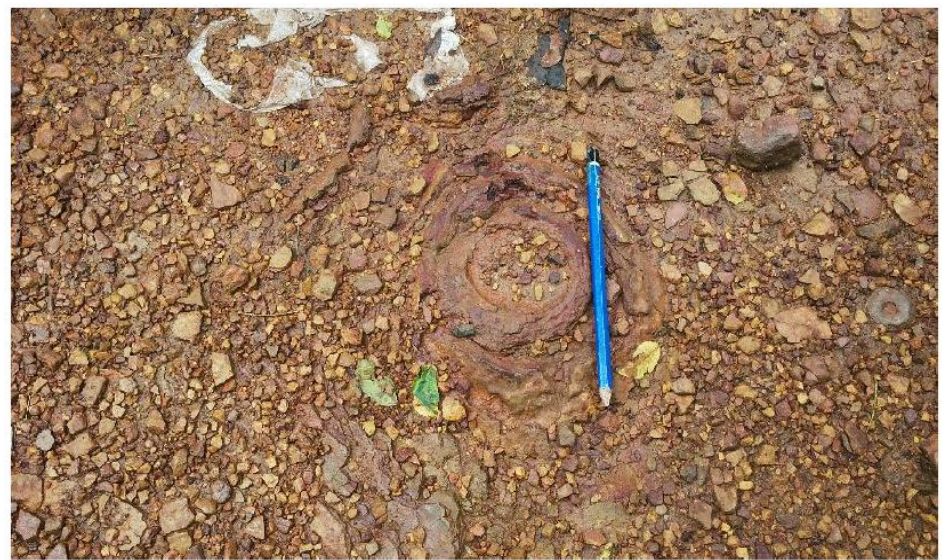

Fig. 8. Concentric diagenetic and epigenetic mineralization at the upper sections of theAjali Sandstone and lower sections of the Nsukka Formation.

\section{Sediment Granulometry}

From the granulometric studies, the Ajali Sandstone is predominantly medium-grainedwith size ranging between 1.33 to 2.10 . The cumulative frequency curves (Fig. 9), display mainly saltation loads with steep slopes. Gravelly, coarse-grained sand togetherwith silt and clay sized particles were generally negligible or of minor components. Themajority of the samples were moderately sorted with a few poorly sorted populationsdue to the mixture of sand with gravel and some clay. The kurtosis was between 0.99 and 4.51 indicative of mainly mesokurtic, leptokurtic and extremely leptokurtic sand.The skewness was mainly symmetrical, positively and negatively skewed with uniformmedium-coarse and fine tail populations for the sorted and poorly sorted populations,respectively.

Bivariate plots of computed univariate parameters, using the discriminatory fieldsproposed by Friedman (1967), Moiola and Weisser (1968) differentiated the adjacentdepositional environments shown in Figs. 10 - 12. 


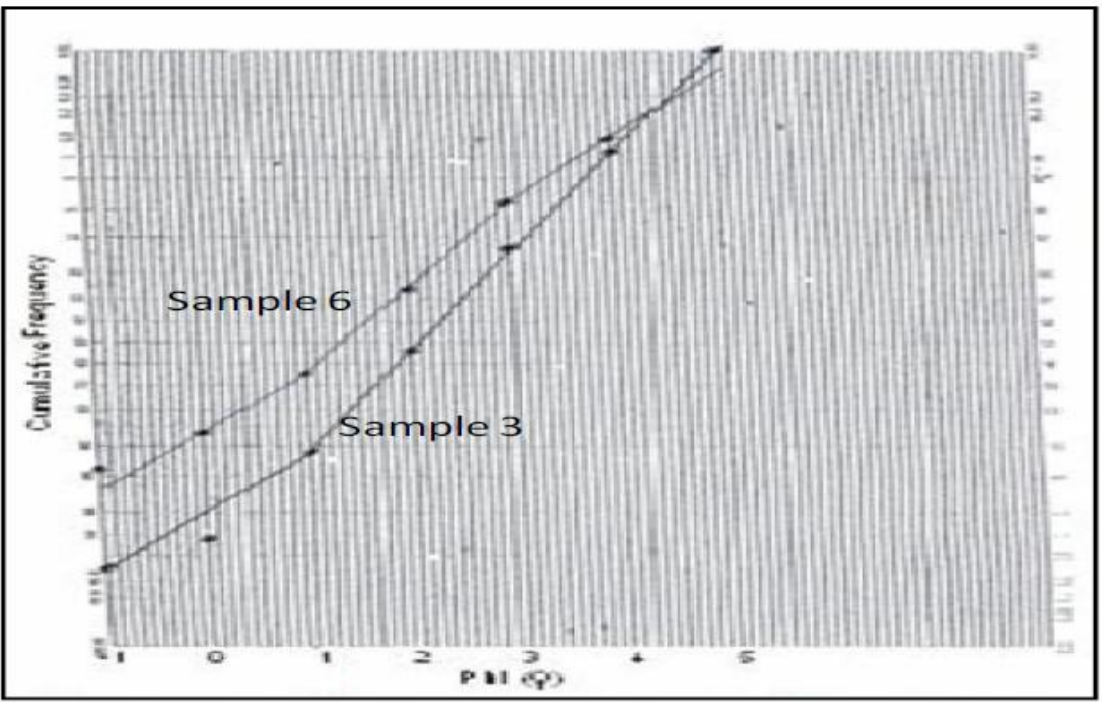

Fig. 9. Representative Cumulative Frequency Curves of some of the analyzed Samples in the Study Area

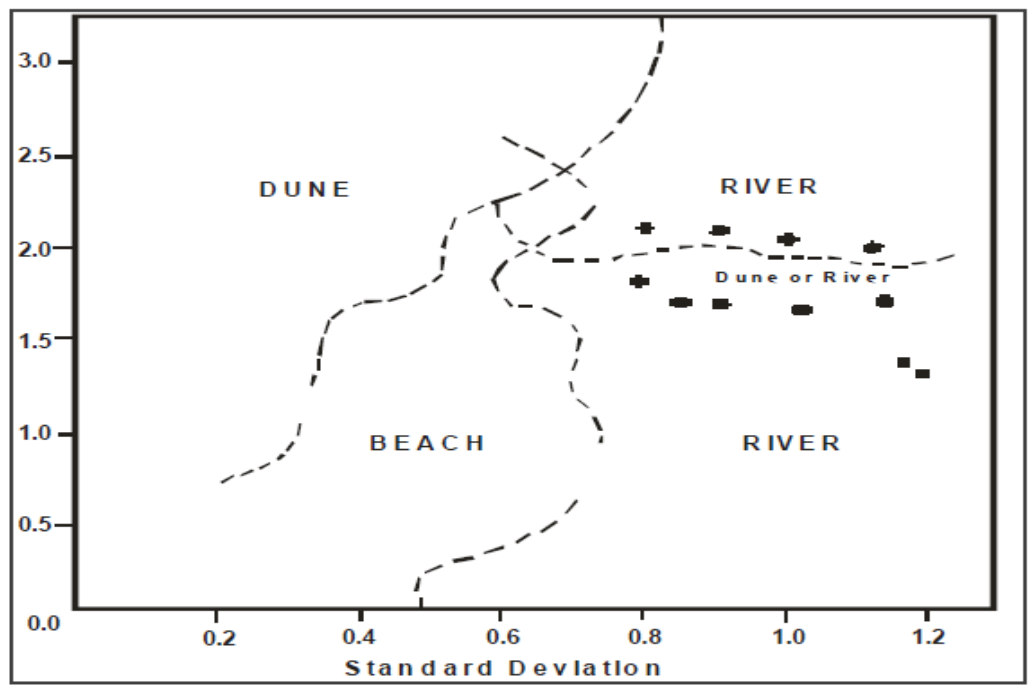

Fig. 10. Bivariate Plots of Skewness Vs Standard Deviation (after, Friedman, 1967)

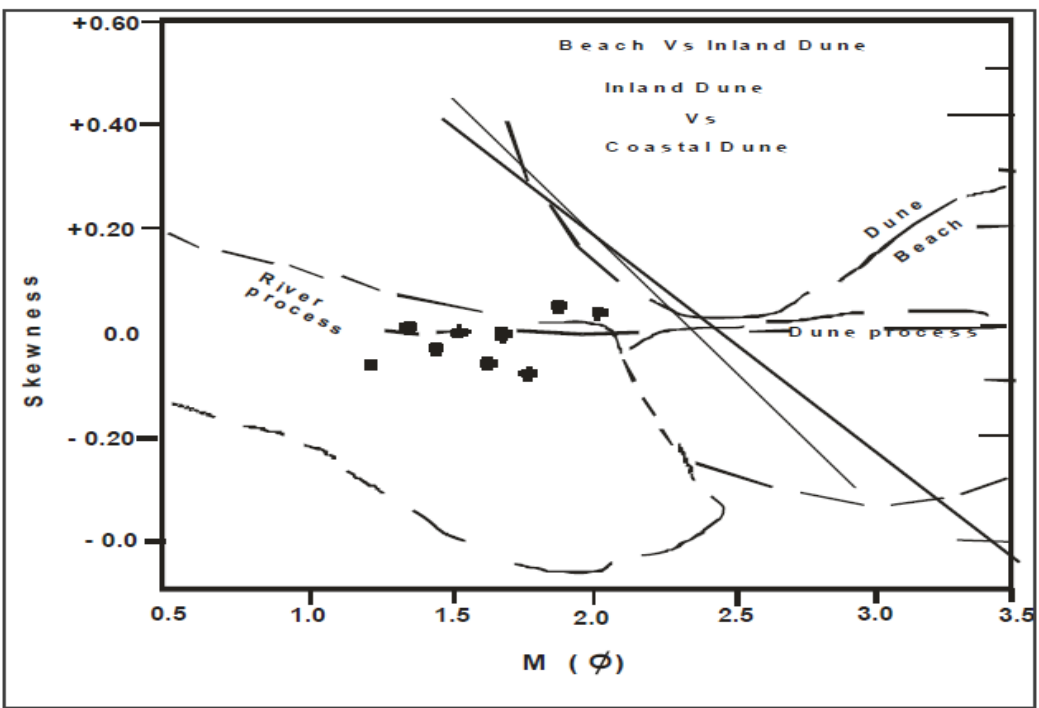

Fig. 11. Bivariate Plots of Skewness Vs Standard Deviation (after, Friedman, 1967) 


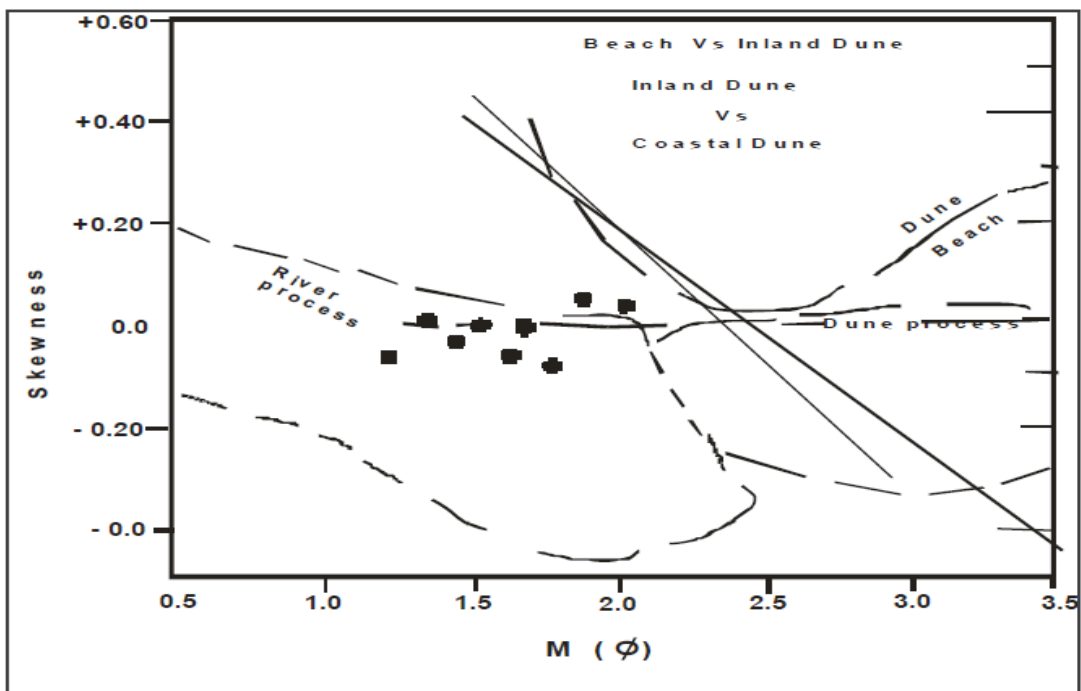

Fig. 12. Bivariate Plots of Skewness Vs Mean Size (after, Meola and Weiser, 1968)

\section{COMPOSITION, MATURITY AND CLASSIFICATION}

Mineralogical study of the Ajali Sandstone revealed the abundance of quartz of fairlyuniform size grades suggestive of moderate sorting (Folk 1974) and generally subroundedto rounded grains (Fig. 13). The average composition of the rocks from thinsection microscopy showed that the average modal compositions of the frameworkelements, cement (iron and silica), and void are 75, 15 and $10 \%$ respectively. Graincounting of quartz, heavy mineral and other minerals that constitute the rock fragmentsrevealed an average composition of the quartz, heavy mineral and other rock fragmentsto be 96, 1 and $3 \%$, respectively. Feldspar was absent in all the studied samples (Fig.13). Feldspar is less stable than quartz in sandstones (Pettijohn, 1975); its total absencefrom the studied samples suggests probable low relief, humid climate, low rate oferosion (Pettijohn, 1975); flat topography in order to effect thorough weathering (Folk, 1980); prolonged weathering, transportation and recycling (Tijani et.al., 2010).With themajor framework elements of the Ajali Sandstone sediments in Igbere area being quartz $(\mathrm{Q})$ and rock fragment (Lithic component) $(\mathrm{R})$. The other element - feldspar which is acommon constituent of most sandstone is absent from the deposits at Igbere. The Qpolewill consist of quartz (Mono-crystalline); Rock fragment (R) and the F-pole(feldspars), which is absent. The percentage modal composition of framework elements(Quartz, feldspar and rock fragment) of the sandstone are as follows: Quartz $-96 \%$,Feldspar $-0 \%$, rock fragment $-4 \%$. The framework elements plotted in the tenarydiagrams of Iwuagwu and Lerbekmo (1982) and Folk (1980) classified the sandstone inthe study area as quartz sandstone and quartz arenite, respectively (Figs. 14 and 15).The ratio of undulatory quartz to total in sandstone is often used as an index of texturalmaturity. Quartz undulosity, therefore, is an indication of high stress state of the grainwith resultant thermodynamics and mechanical instability (Blatt and Christie, 1963;Nwajide and Hoque, 1985). The quartz in the samples is rich in non undulosemonocrystalline species suggestive of prolonged domiciliation in sedimentaryenvironment with consequent selective elimination of undulatory grains by bothmechanical and chemical processes. The high percentage $(96 \%)$ of mono-crystallinequartz in the samples probably is due to dilution of the original plutonic detritus by nonundulatoryquartz grains derivable from an older sedimentary terrain (Nwajide andHoque, 1985). The average mono-crystalline quartz in samples from Igbere area is 96 $\%$ thus making it a super mature sandstone (Blatt and Christie, 1963).

The heavy minerals consist of a narrow suite of ultra-stable species including Zircon,Tourmaline and Rutile with ZTR Index of over $90 \%$ (Hubert, 1962). The Zirconincluded types J3, L5, M1, P5, S1-S10, S12, S15, S19, U20 of Pupin (1967) which typicallyhave their origin from crystalline Basement Complex (Pupin, 1967). Agumanu (1993)concluded from the deposited Owelli Sandstone (Maastrichtian) in the adjacentSouthern Benue Trough with the lithic fill of the Afikpo Basin, that diastrophism of thesource and tectonics of the depositional area probably controlled the concentration ofthe ultra-stable heavy minerals. This is because tectonism enhances the maturity ofsandstone and determines the assemblage of heavy mineral species (Hubert, 1962). TheZTR index of the sandstone being over $90 \%$ (Hubert, 1962) thus confirms themineralogical maturity of the sandstone in the study area. Using the quartz-feldsparratio in the Ajali Sandstone (Q96 F0 R4) as an index of mineralogical maturity(Pettijohn, 1949), and applying Nwajide's and Hoque's (1985) expression for maturityindex: $(\mathrm{Q} / \mathrm{F}+\mathrm{R})$ which is Pettijohn's compositional maturity: it follows that the AjaliSandstone is mineralogically super mature with a maturity index >19; it is a quartzarenite/quartz sandstone which agrees with Folk's (1980) and the conclusion ofIwuagwu and Lerbekmo (1982) that "measures the progress towards the ultimate endtype-a pure quartz sand" (Pettijohn, 1975). 


\section{Paleocurrent Pattern}

The paleocurrent attributes used in the study included trough and planar cross-beds andripple marks. Pebble imbrications and sole marks were not readily available. BecauseAjali Sandstone is synonymous with cross-beds (the False Bedded Sandstone ofSimpson, 1954), the study depended on them to determine paleocurrent rose diagramswhich were prepared from the Azimuth of trough and dip of planar cross-beds. Rosediagrams with a class interval of $30^{\circ}$ were adopted (Figure 16). Dip corrections weremade for dips greater than $15^{\circ}$ (Ramsay, 1961). The current direction indicated by thecross-beds was mainly unimodal in the west-southwest within $90^{\circ}\left(180-270^{\circ}\right)$ sector

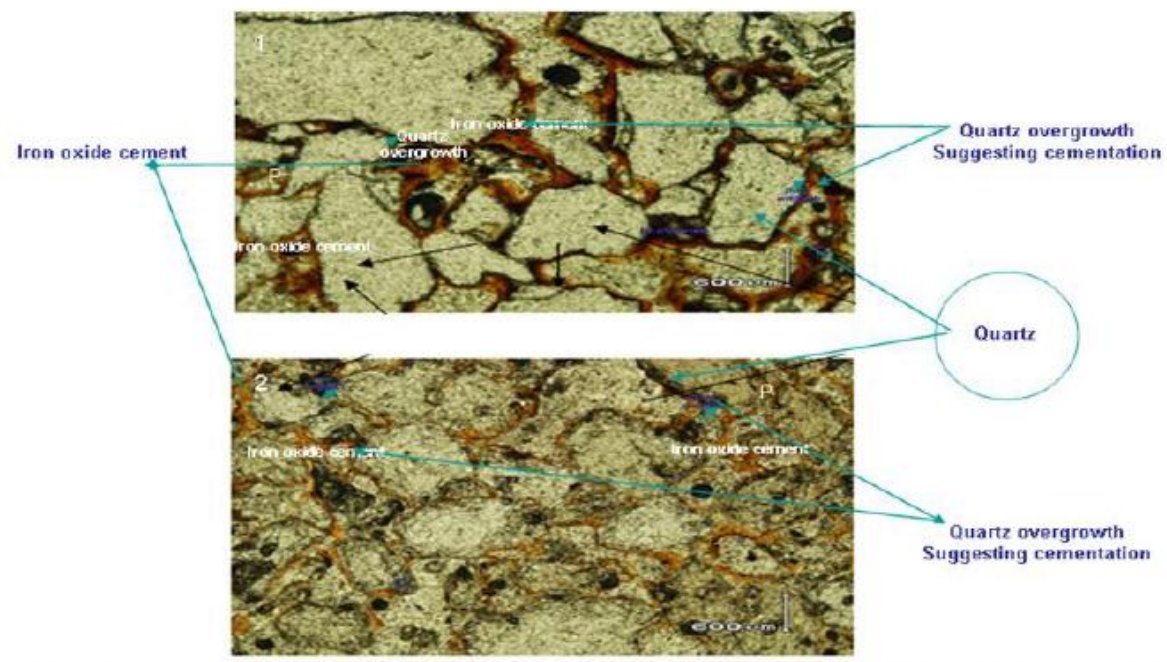

Fig. 13. Representative Photomicrographs of Ajali Sandstone Sediments in the Study Area

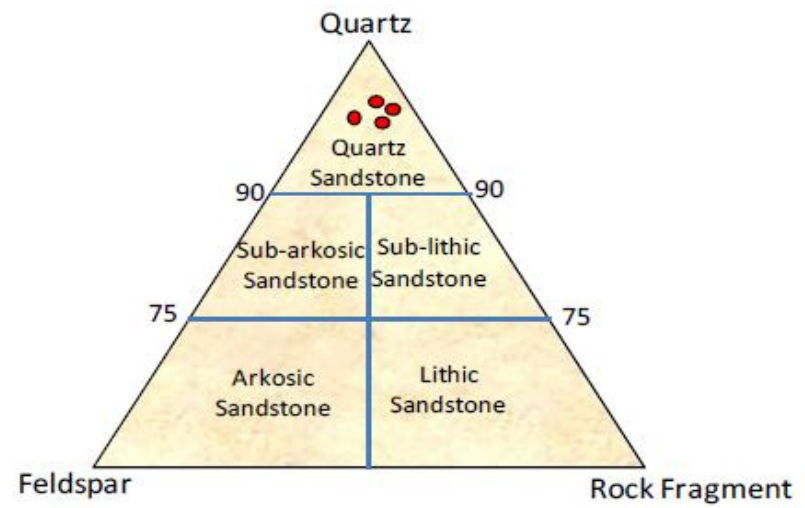

Fig 14. Classification of sandstone (after Iwuagwu and Lerbekmo, 1982)

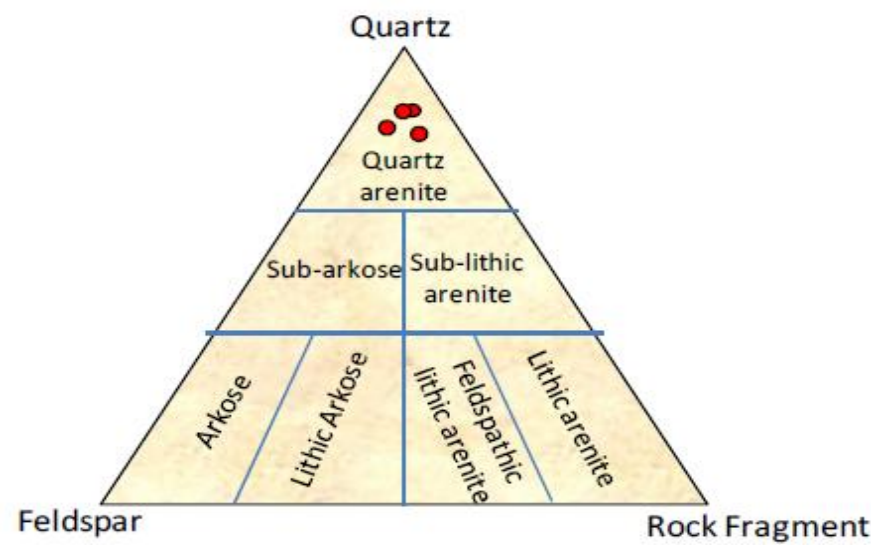

Fig 15. Classification of sandstone using the scheme of Folk (1974) 

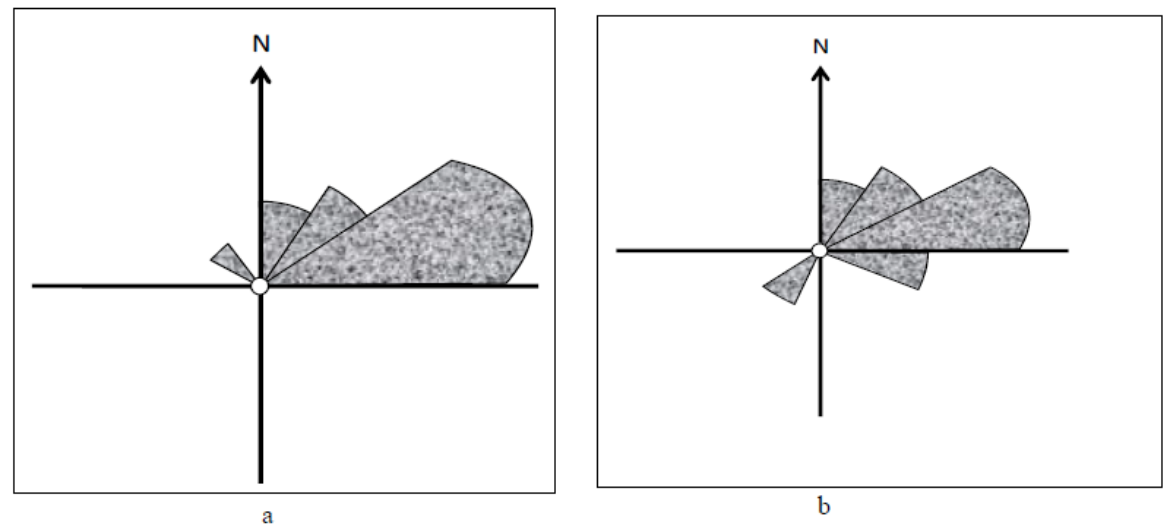

Fig. 16 a and b. Rose Diagrams showing unimodal current direction in the westsouthwest

\section{SUMMARY AND CONCLUSION}

The study synthesized data accruing from lithofacies, sedimentary structures, petrologyand paleocurrent trend to infer paleoenvironment, source model and paleogeography ofthe lithostratigraphic units in Igbere area, Afikpo Basin.The analyses of the stratigraphic sections in the area of study distinguished fivelithofacies namely, pebbly sandstone facies, cross-bedded sandstone facies, laminatedsandstone, bioturbated sandstone and mudstone facies. The sequence, from the base,comprised of pebbly and coarse grained facies, through trough and planar cross-beddedfacies in the middle section, terminating with mudstone facies at the upper sections, thusstimulating a generally fining-upward (FU) sequence. The inferred depositionalenvironment is fluvial with tidal influences. The granulometric studies have shown thatthe Ajali Sandstone is predominantly mediumgrained with sizes ranging between 1.33 to 2.10phi. Petrographic study of the Ajali Sandstone revealed the abundance of quartzof fairly uniform size grades and generally sub-rounded to rounded grains suggestive ofmoderate sorting. The average composition of the rocks from thin section microscopyshowed that the average modal compositions of the framework elements, cement (ironand silica), and void are 75, 15 and $10 \%$ respectively. Grain counting of quartz, heavymineral and other minerals that constitute the framework elements revealed an averagecomposition of the quartz and rock fragments to be 96,1 and $3 \%$ respectively. Feldsparwas absent in all the studied samples and the percentage modal composition offramework elements (Quartz, Feldspar and Rock Fragments) of the sandstone are asfollows: Quartz - $96 \%$, Feldspar - $0 \%$, Rock Fragment $-4 \%$. The Ajali Sandstone inIgbere area was therefore expressed as mineralogically super mature deposit with amaturity index $>19$ and also classified as quartz arenite based on ternary diagrams'plots. As a super mature deposit, therefore, the deposition of the Ajali Sandstonesediments in the Afikpo Basin can be said to have occurred in more than one cycle(polycyclic) of sedimentation. The accompanying heavy minerals consist of a narrow suite of ultra-stable speciesincluding Zircon, Tourmaline and Rutile with ZTR Index of over $90 \%$, thus confirmingthe mineralogical maturity of the Ajali SandstoneThe paleocurrent direction deduced from cross-beds was mainly unimodal in the westsouthwest,within $90^{\circ}\left(180-270^{\circ}\right)$ sector. The super maturity status and thepaleocurrent directions of the Ajali Sandstone sediments in the study area are indicativethat detritus were sourced from both the uplifted continental pluton and old sedimentarydomain, respectively. The Crystalline Basement rocks of both the Cameroon andAdamawa Highlands, the Oban Massif and western Nigeria Ilesha Spur on the one handand the Abakaliki Anticlinorium on the other both satisfied such source models for the post-Santonian Ajali quartz-sand deposit.

\section{REFERENCES}

[1]. Agumanu, A.E., 1986. Sedimentary Geology of part of the southern Benue Trough,Ph.D. Thesis, University of Ife. 475pp.

[2]. Agumanu, A.E., 1989. The Abakaliki and Ebonyi Formations: sub-divisions of theAlbianAsu River Group in the southern Benue Trough, Nigeria. Jour. Afr.Earth Sci., 9, p. 195-202.

[3]. Agumanu, A.E., 1993. Sedimentology of Owelli Sandstone (Campano - Masstrichtian)Benue Trough. J. Min. Geol Vol. 29, No. p. 21-35.

[4]. Agumanu, A.E., 2009. Storm-influenced Tidal Epeiric Seas: An Example from theCretaceous southern Benue Trough, Nigeria. Global Journal of GeologicalSciences, Vol. 7, No. 2, p. 151-169.

[5]. Agumanu, A.E., 2011. Environment of Deposition of the Awgu Formation (LateCretaceous), Southern Benue Trough, Nigeria. Global Journal of GeologicalSciences, Vol. 9, No. 2, p. 215-228

[6]. Allen, R.L., 1981. Lower Cretaceous Tide revealed by cross-bedding with mud drapes.Nature No. 286, p.579-581.

[7]. Amajor, L.C., 1986. Sedimentary Facies Analysis of Ajali Sandstone (upperCretaceous) in the southeastern Benue Trough Nigeria, Bull., Nig. Jour. Min.Geosc. Soc. Vol. 21, p.171-176.

[8]. Amajor, L.C., 1987. Paleocurrent, Petrography and Provenance Analysis of the AjaliSandstone (Upper Cretaceous) Southeastern Nigeria, Sedt. Geol. Vol. 55, p.47-60.

[9]. Anyanwu, N.P.C. and Arua, I., 1990. Ichnofossils from the Imo Formation and theirpaleoenvironmental significance. J. Min. and Geol., Vol. 26. p.1-4. 
[10]. Arua, I., 1988. Episodic Sedimentation: an example from the Nkporo Shale (Campano-Maastrichtian), Nigeria. Journal African Earth Science. Vol. 7, p.72 - 759.

[11]. Banerjee, I., 1980. A subtidal Bar model for the Eze-Aku sandstones. Nigeria.Sediment. Geol. 25, 291-309

[12]. Blatt, H. and Christie, J.M., 1963. Undulatory extinction in quartz of igneous andmetamorphic rocks and its significance in provenance studies of sedimentaryrocks. J. Sediment. Petrol., 33: 559--579.

[13]. Braide, S.P., 1992. Geological development, origin and energy mineral resourcespotential of the Lokoja Formation in the southern Bida Basin. Journal of Miningand Geology 28, 33-44.

[14]. Bridge, J.S., Jalfin, G.A. and Georgieff, S.M. 2000. Geometry, Lithofacies and SpatialDistribution of Cretaceous Fluvial Sandstone Bodies, San Jorge Basin,Argentina Outcrop Group. J. Sed. Res. Vol. 70, p.341-360.

[15]. Burke, K. C., T. F. J. Dessauvagie, and A.J. Whiteman, 1972, Geological history ofthe Benue valley and adjacent areas, in T. F. J. Dessauvagie and A.J.Whiteman, eds., African Geology: Univ. Ibadan, p. $187-206$

[16]. Coleman J.M and Gangliano S.M, 1965. In: G.V Middleton 9Editor) Primarysedimentary structures and their hydrodynamic interpretation. Soc. Econ.Paleontology. Mineral. Spec.Publ., Vol.12, p.133-248

[17]. Dessauvagie, T. F. J. 1975. Explanatory Note to the geological map of Nigeria. -Nigerian J. Min.GeoZ., 9, 1-29.

[18]. Dill, H.G., 2012. Diagenetic and epigenetic mineralization in Central Europe related tosurfaces and depositional systems of sequence stratigraphic relevance. Journal ofSedimentary Research, Vol. 77, p.702-712

[19]. Doe, T. W., And Dott, R. H., JR., 1980, Genetic significance of deformed crossbedding--with examples from the Navajo and Weber Sandstones of Utah: Jour.Sed. Petrology, Vol. 50, p.793-812.

[20]. Folk, R.L., 1980. Petrology of Sedimentary Rocks. Hemphill Publishing, Austin, TX,184p.

[21]. Friedman, G.M. 1967. Dynamic Processes and Statistical Parameters Compared for sizefrequency distribution of Beach and River Sands. J. Sed. Petrol., Vol.37, p.327-354

[22]. Hoque M., 1977. Petrographic Differentiation of Tectonically Controlled CretaceousSedimentary Cycles, southeastern Nigeria. Sedim Geol., Vol.17, p.235-245.

[23]. Hoque M., and Nwajide C.S., 1985. Tectono-sedimentological evolution of an elongateintracratonic basin (aulacogen): The case of the Benue Trough of Nigeria.Journal of Mineralogy and Geology. Vol. 21 (1-2), p.19-26

[24]. Hoque, M. and Ezepue, C.M., 1977. Petrology and Paleogeography of the AjaliSandstone. J. Niger. Min. Geosci. Soc., V.14, p.1622.

[25]. Hubbert, J.E., 1962. Zircon-tourmaline-rutile maturity index and the interdependence ofthe composition of heavy mineral assemblages with the gross composition andtexture of sandstones. Jour.Sed.Petrology. Vol. 32, p.440-450.

[26]. Ibe, K.K., 2004. Preliminary Geochemical Classification of Ajali Sandstone Units inOhafia Area Southeastern Nigeria. In: Advances in Geosciences. Journ.Geosci., Dept. of Geol, Federal University of Technology Owerri. Vol. 2, No.3, p. 11-17.

[27]. Iwuagwu, C.J. and Lerbekmo, J.F. 1982. The Petrology of the Basal Belly RiverSandstone Reservoir, Peimdina Field, Alberta. Bull. Can. Petrol. Geol., Vol.30,No. 3, p.187-207.Jones, B.G 1961. Sedimentary structures in the Bima Sandstone. Niger Geol.Surv.6:14pp.

[28]. Ladipo, K.O 1986. Tidal shelf depositional model for the Ajali Sandstone, AnambraBasin Southeastern Nigeria. Journal African Earth Science 5, 177-185

[29]. McKee, E.D., Reynolds, M.A. \& Baker, C.H., 1962. Laboratory studies on deformationin unconsolidated sediment. United States Geological Survey, ProfessionalPaper 450-D, D151-D155.

[30]. Miall, A.D., 1992. Alluvial deposits. In: Walker, R.G., James, N.P. (Eds.), FaciesModels: Response to Sea Level Change. Geological Association of Canada,p.119-142.

[31]. Moiola, R.J. and Weisser, D., 1968. Textural Parameters: and Evaluation. Journal Sed.Petrol, Vol. 38, p. 45-53.

[32]. Murat R.C., 1972. Stratigraphy and Paleogeography of the Cretaceous and LowerTertiary in Southern Nigeria. In Dessauvagie, T.T.J., and white man, A.J. (Eds),African Geology, University of Ibadan Press, Nigeria, p. 251-266.

[33]. Nwachukwu, S.O., 1972. The Tectonic Evolution of the southern portion of the BenueTrough, Nigeria: Geology Magazine, Vol. 109, p. 411-419.

[34]. Nwajide, C. S. (1982). "Petrology and Paleography of the Makurdi Formation”.Unpublished Ph.D. Thesis, Department of Geology, University of NigeriaNsukka.

[35]. Nwajide, C.S. 2006. A Guide for Geological Field Trips to the Anambra Basin andrelated Sedimentary Basins in southern Nigeria. Great A.P Publishers. p. 55-59

[36]. Nwajide, C.S. 1985. “A Systematic Liithostratigraphy of the Makurdi Sandstones,Benue Trough”. Journal Mining and Geology. Vol. 22, p.9-23

[37]. Nwajide, C.S., 2005. Anambra basin of Nigeria: Synoptic Basin Analysis as a Basis forEvaluation its Hydrocarbon Prospectivity, In Okogbue, C.O., (Ed.),Hydrocarbon potentials of the Anambra Basin, PTDF Chair, p.2-46.

[38]. Odigi, M.I., (2012), "Sedimentology of the Nkporo Campanian-MaastrichtianConglomeratic Formation, Afikpo Sub-basin, Southern Benue Trough, Nigeria",Journal of Mining and Geology, 48, no. 1, p. 45 - 55.

[39]. Ojoh, K.A., 1990. Cretaceous Geodynamic Evolution of the southern part of theBenue Trough (Nigeria) in the equatorial Domain of the south AtlanticStratigraphy Basin Analysis and Paleogeography. Bull. CentresRech.Explor-Prod, Elf-Aquaintine, v.14, p. 419442 .

[40]. Olade MA (1975). Evolution of Nigeria‘s Benue Trough (aualcogen): A tectonic model.Geol. Mag. Vol. 112, p. 575-578.

[41]. Onyekuru S.O., Iwuagwu, C.J., Nwankwor, G.I., Onu, N.N. and Ukaonu, C.E., 2013.Dispersal Patterns of the Late Cretaceous to Early-Tertiary Sediments in theSouthern Anambra Basin, Southeastern Nigeria. International Journal ofGeosciences, 2013, Vol, 4, p. 588-604

[42]. Onyekuru, S.O, Iwuagwu, C.J. 2010. Depositional Environments and sequencestratigraphic interpretation of the CampanoMaastrichtian Nkporo Shale Groupand Mamu Formation exposed at Leru-Okigwe axis, Anambra Basin,Southeastern Nigeria. Australian Journal of Basic and Applied Sciences, Vol,4(12), p.6623-6640.

[43]. Petters, S.W. and E. Ekweozor. 1982. "Central West African Cretaceous-TertiaryBenthic foraminifera, Stratigraphy and Paleontolographia. Abt. 1979, p. 1-104.

[44]. Petters S.W., 1978. Stratigraphic evolution of the Benue Trough and its implication forthe Upper Cretaceous paleogeography of West Africa. Jour.Geol. Vol. 86,pp311-322

[45]. Pettijohn F.J., 1975 Sedimentary rocks. 3rd ed. Harper and Row, New York, 682p.

[46]. Pettijohn F.J., Potter, P.E. and Siever R. 1987. Sand and Sandstone. Springer, NewYork, 553 p.

[47]. Pupin, J .P. 1980 - Zircon and granite petrology. Contrib. Mineral Petrol, Vol. 73,p.207.220.

[48]. Ramsay, J.G 1961. The effects of folding upon the grain orientation in determination ofPaleocurrent and sandstone trend. Bull.Am.Ass.Petrol. p.1052-1066 
[49]. Reineck, H. E. and Singh, I. B., 1975. Depositional Sedimentary Environments, withReference to Terrigenous Clastics. Springerverlag, Berlin, p. 4-27.

[50]. Reyment, R.A., 1965. Aspects of the Geology of Nigeria: The Stratigraphy of theCretaceous and Cenozoic Deposits. University of Ibadan Press, 145p.

[51]. Simpson, A. 1954. The Nigerian coalfield: The geology of part of Owelli and Benueprovinces. Bull. Geol. Surv. Nigeria. No. 24 , $85 \mathrm{p}$.

[52]. Samaila, N. K., Braide, S.P., Dike, E.F.C., and Cheo, E.S., 2005. Study of soft-sedimentstructures in the Cretaceous Bima Sandstone, Upper Benue Trough,northeastern Nigeria. Journal of Mining and Geology. Vol.41 (1), p.81-86

[53]. Tijani M.N., Nton, M.E., and Kitagawa, R., 2010. Textural and geochemicalcharacteristics of the Ajali Sandstone Anambra Basin, SE Nigeria: Implicationfor its provenance. C.R Geocience. Vol. 342, p.136-150.

[54]. Tijani, M.N. and Nton,M.E. (2009). Hydraulic, Textural and Geochemicalcharacteristics of the Ajali Formation, Anambra Basin, Nigeria: Implication forgroundwater quality. Environmental Geology, Vol. 56, p. 935-951

[55]. Umeji, O.P., 2010. Palynostratigraphy, Sequence stratigraphy and palaeoecology of theCampanian-Maastrichtian Nkporo Group in Afikpo-4 well, Afikpo Syncline,southeastern Nigeria. Journal of Mining and Geology, Vol. 46, No.1, p.93-112

[56]. Wakelin-King, G.A. and Webb, J.A., 2007. Upper flow regime mud flood plain andlower flow regime sand channel: sediment transport and deposition in Dry LandAggregate River. Journal of sedimentary research, Vol. 77, p.702-712 